A description of detailed experiments will soon appear.

Research LABORATORY FOR SOILS, UNIVERSITY OF CALIFORNIA

\section{THE WATER CONTENT OF THE EMBRYONIC NERVOUS SYSTEM}

GrowTH and morphological differentiation go hand in hand in the developing organism, but obviously growth alone can not lead to an increase in the complexity of form without itself being differential. The various tissues and organs of the embryo, however, do grow at different rates, and since, in general, rate and extent of growth are measurable in terms of the rate and extent of water absorption, it follows that differential growth must depend on the ability of the embryonic tissues to absorb and hold, relative to their dry substance, different amounts of water. That this must be true at some period in development follows from the comparative dry substance determinations familiar to every one, but how early in the ontogeny differential absorption occurs has not been known, although its importance as a factor in morphological differentiation has been hinted at often enough.

$\mathrm{My}$ investigation of this question was begun on the embryos of Rana pipiens in the spring of 1913. The methods employed were tedious but simple. In one series of experiments eggs were allowed to develop normally until a time when the body of the embryo could be cut from the yolk by means of a very thin knife. The division was accomplished easily with a minimal loss of material. Unfortunately the various tissues in the separated portions can not be isolated, but even if this were possible, an unavoidable error due to the presence of considerable quantities of yolk within the cells of the nervous system would remain. However, at the stage of development under consideration, it is safe to assume that the operation results in the separation of two masses, one of which is predominantly yolk, the other, predominantly nervous tissue.

The separated masses were carefully weighed in closed ressels after removal of the super- ficially adhering water. Following the determination of the fresh weight, the material was reduced to absolute dryness in vacuo over $\mathrm{P}_{2} \mathrm{O}_{5}$. The results of two series of weighings given in Table $\mathrm{I}$. are:

TABLE I

(Rana pipiens)

\begin{tabular}{|c|c|c|c|c|}
\hline & 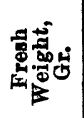 & 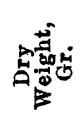 & 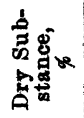 & ${ }^{5}$ \\
\hline $\begin{array}{l}24 \text { yolk sacs. . . . . . . . } \\
31 \text { yolk sacs. . . . . . }\end{array}$ & $\begin{array}{l}.0440 \\
.0585\end{array}$ & $\begin{array}{l}.0204 \\
.0264\end{array}$ & $\begin{array}{l}46.4 \\
45.2\end{array}$ & $\begin{array}{l}53.6 \\
54.8\end{array}$ \\
\hline Average........... & & & 45.8 & 54.2 \\
\hline $\begin{array}{l}24 \text { nervous systems. . . . } \\
31 \text { nervous systems. . . }\end{array}$ & $\begin{array}{l}.0464 \\
.0714\end{array}$ & $\begin{array}{l}.0098 \\
.0149\end{array}$ & $\begin{array}{l}19.1 \\
20.8\end{array}$ & $\begin{array}{l}80.9 \\
79.2\end{array}$ \\
\hline Average........... & & & 19.9 & 80.1 \\
\hline
\end{tabular}

Control observations on embryos of Amblystoma punctatum were then made, but, owing to technical difficulties, it proved easier to compare the water content of the nervous system with that of the entire embryo rather than with that of the tissues constituting the yolk sac. The results of these preliminary determinations were as follows:

TABLE II

(Amblystoma larvæ)

\begin{tabular}{|c|c|c|c|c|}
\hline & 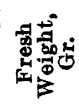 & 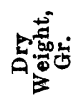 & 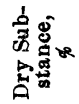 & 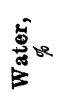 \\
\hline 16 larvæ........... 15 & $\begin{array}{l}.0955 \\
.0992\end{array}$ & $\begin{array}{l}.0399 \\
.0406\end{array}$ & $\begin{array}{l}41.8 \\
40.9\end{array}$ & $\begin{array}{l}58.2 \\
59.1\end{array}$ \\
\hline Average. . . . . . . . . & & & 41.4 & 58.6 \\
\hline
\end{tabular}

These figures may serve as a basis for comparison with the water content of the nervous system. As Table III. shows, the values for the latter are identical with those for the frog embryo, and belong to an order of magnitude quite different from the values for the larval body taken as a whole.

Comparing these values with the corresponding ones found for the frog embryos, we may say, within the limits of error, that the larval nervous system of these amphibians is a tissue which contains 80 per cent. of water and 20 per cent. of dry substance. 
TABLE III (Amblystoma larvæ)

\begin{tabular}{|c|c|c|c|c|}
\hline 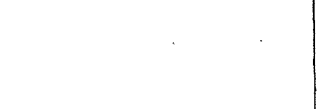 & 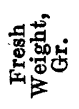 & 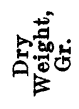 & 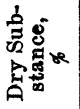 & $\underbrace{5}$ \\
\hline $\begin{array}{l}52 \text { nervous systems. . . . } \\
15 \text { nervous systems. . . . } \\
69 \text { nervous systems..... }\end{array}$ & $\begin{array}{l}.1756 \\
.0524 \\
.2039 \\
\end{array}$ & $\begin{array}{l}.0400 \\
.0106 \\
.0363 \\
\end{array}$ & $\begin{array}{l}22.8 \\
20.2 \\
17.8 \\
\end{array}$ & $\begin{array}{l}77.2 \\
79.8 \\
82.2 \\
\end{array}$ \\
\hline Average........... & & & 20.3 & 79.7 \\
\hline
\end{tabular}

If we wish to institute a comparison between the water content of the embryonic nervous system and the corresponding adult structure, it is more correct to use the water content of the cord, for this is less differentiated than the brain and consequently more nearly resembles the larval condition. Donaldson ${ }^{1}$ has given the water content of 12 cords of Rana pipiens. The average is 80.5 -identical with my value of 80.1 for the larval system.

Comparisons were also made between the water content of the anterior and posterior ends of the embryonic nervous system. For this purpose I divided 125 isolated larval nervous systems of Amblystoma in two, as accurately as possible, in the medullary region. Dry substance determinations of the separated portions were then made with the following results:

TABLE IV

(Amblystoma)

\begin{tabular}{|c|c|c|c|c|}
\hline & 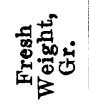 & 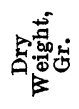 & 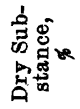 & 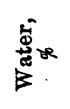 \\
\hline $\begin{array}{l}125 \text { larval brains } \\
125 \text { larval cords }\end{array}$ & $\begin{array}{l}.1812 \\
.2102\end{array}$ & $\begin{array}{r}.0342 \\
.0443 \\
\end{array}$ & $\begin{array}{l}17.2 \\
21.0 \\
\end{array}$ & $\begin{array}{l}82.8 \\
79.0\end{array}$ \\
\hline
\end{tabular}

These results are in the same sense as those reported by Donaldson, ${ }^{2}$ as the water content of the brain of an adult Rana pipiens is 84.9 per cent., or 4.4 per cent. higher than that of the cord. My results on Amblystoma indicate that the larval brain contains more water than the attached cord.

1 Donaldson, Henry H., " Further Observations on the Nervous System of the American Leopard Frog, Rana pipiens, etc.,' Journal of Comparative Neurology and Psychology, Vol. 20, p. 2.

2 Loc. cit., p. 2.
We may conclude, therefore that the nervous system as a whole has a specific capacity for holding water and that this specificity exists from the beginning. This can be the outcome of nothing other than a physical-chemical specificity, and we must suspect that the nervous system differentiates as a morphological entity, because its chemical differentiation endows it with a specific capacity for holding water. Moreover, two regions as sharply distinct, morphologically and physiologically, as brain and cord have each their own specific capacities, and these although not differing as widely, perhaps, as in the adult, are nevertheless at variance in the embryo in the same sense. The thought lies near at hand, therefore, that the gross structural differences between brain and cord brought about during the course of development are definitely related to the fact that their respective rudiments maintain each its own specific relation between the amount of dry substance and the amount of water.

\section{UNIVERSITY OF MICHIGAN, April 3, 1914}

\section{Otto Glaser}

\section{CONFERENCE ON INDIVIDUAL PSYCHOL- $O G Y$}

Former pupils of the department of psychology of Columbia University held a reunion and conference at the university, on April 6-8, and on the latter date gave a dinner to Professor James McKeen Cattell in celebration of the twenty-fifth anniversary of his first appointment as professor of psychology. This first appointment was at the University of Pennsylvania, and Professor Witmer, of that institution, one of Professor Cattell's earliest students, participated in the dinner. On this occasion a volume entitled "The Psycholog: ical Researches of James McKeen Cattell: A Review by Some of His Pupils,', written by Messrs. Thorndike, Wells, Henmon, Dearborn, Hollingworth and Woodworth, was presented to Professor Cattell.

The program of the Conference follows:

Monday, April 6, at 3 P.M.

Chairman, Professor CATtell

"Individual Differences in Sense Discrimina. tion"': V. A. C. HENMON (Ph.D., 1905), professor 